\title{
Portal Doppler ultrasound evaluation in myelitis by Schistosoma mansoni
}

\author{
Claudio Henrique Fernandes Vidal ${ }^{1}$, Fernando Viana Gurgel ${ }^{5}$, \\ Maria Lucia Brito Ferreira³, Ana Lúcia Coutinho², \\ Hildo Rocha Cirne de Azevedo Filho ${ }^{1,4}$
}

\begin{abstract}
The mechanism for development of schistosomal myelitis has not yet been completely understood. Few publications have tried to establish a link between the general clinical presentation of the illness and its neurological manifestations. Objective: To evaluated the portal blood flow in patients with schistosomal myelitis and controls. Method: Fortythree individuals were evaluated using portal Doppler ultrasound. Group I consisted of 13 patients with the spinal form of schistosomiasis. Group II included 10 patients with intestinal and hepatointestinal forms of schistosomiasis, but no neurological symptoms; while group III involved 20 healthy controls. Results: Portal venous speed and portal venous flow were significantly elevated in group I $(p<0.001)$ compared with the others. Conclusion: Doppler ultrasound demonstrated a situation of high flow within the portal venous system of patients with schistosomal myelitis.

Key words: schistosomiasis mansoni, neuroschistosomiasis, myelitis, portal system.
\end{abstract}

\section{Avaliação pela ultrassonografia com Doppler portal na mielite pelo Schistosoma mansoni}

\section{RESUMO}

A fisiopatogênese da mielopatia esquistossomótica não é completamente entendida, sendo escassas as publicações que tentam inferir a relação entre a forma clínica da esquistossomose e suas manifestações neurológicas. Objetivo: Avaliar o fluxo sanguíneo do sistema porta em pacientes com mielite esquistossomótica, contribuindo no entendimento dos mecanismos que favorecem a chegada dos parasitas e/ou seus derivados ao sistema nervoso. Método: Foram avaliados 43 indivíduos pela Dopplerfluxometria portal. O grupo I constou de 13 pacientes com esquistossomose medular, sendo o grupo II composto por 10 portadores de formas intestinal e hepatointestinal (sem doença neurológica), e o grupo III, por 20 controles sadios. Resultados: A velocidade venosa portal e o fluxo venoso portal foram significativamente elevados $(p$-valor $<0,001)$ no grupo I. Conclusão: $A$ Dopplerfluxometria demonstrou a presença de estados hiperdinâmicos do leito vascular porta em pacientes com mielite pelo Schistosoma mansoni.

Palavras-chave: esquistossomose mansoni, neuroesquistossomose, mielite, sistema porta.

Correspondence

Claudio Henrique F. Vidal Rua Francisco da Cunha 206 51020-041 Recife PE - Brasil

E-mail: vidal-claudio@ig.com.br

Received 16 April 2009

Received in final form 16 August 2009

Accepted 19 September 2009
The nervous system (NS) is the most common ectopic foci of Schistosoma mansoni infection, and its involvement may lead to a broad range of complications. Post-mortem studies have shown that 20 to $30 \%$ of the patients with schistosomiasis have a NS lesion. Therefore, the number of asymptomatic individuals isare nearly three times the number who actually develop neurological symptoms ${ }^{1}$. In neuroschistosomiasis, the spinal cord is the most common place of the disease ${ }^{2}$. The exact frequency of myelopathy in these patients has never been properly studied, in part because of the wide variations in clinical expression $^{3}$. Nowadays, neuroschistosomi- 
asis is considered the third most common cause of myelopathy, after traumatic and tumor involvements ${ }^{4,5}$. The NS lesion may occur at any point once the adult female parasite has laid her eggs, between the $27^{\text {th }}$ and $48^{\text {th }}$ days of infection. However, NS lesions are more common in the initial clinical systemic forms, during the latent period or during chronic mild forms of the disease ${ }^{6-8}$.

The presence and clinical significance of neurological lesions depend on the combination of the presence of eggs and the immune response of the host. In the majority of cases, there is a delayed immune response type four or granulomatous, which is higher in the beginning of schistosomiasis; while in the chronic forms it becomes localized and milder ${ }^{6}$. Batson ${ }^{9}$, in 1940, described the veins of the spine as a system working in parallel to the cava venous system. Through the rectal plexus, there is free communication between the portal and the systemic venous system ${ }^{10}$. With the less severe clinical form of schistosomiasis (intestinal and hepatointestinal), the eggs reach the nervous system through Batson's plexus, and sudden augmentation of abdominal pressure may facilitate this event ${ }^{8}$. A predilection for the lowest spinal cord segments might be caused by the egg's lateral thorn, which may hinder its further migration ${ }^{11}$. On the other hand, Pitella ${ }^{6}$ believed that the migration of the female worm to neural tissue, and the deposition of eggs "in situ" is the most important mechanism involved in development of symptomatic forms of the disease, due to the high concentration of eggs in this situation. In the severe forms of schistosomiasis with portal hypertension, the eggs reach the NS in a diffuse setting, due to ther porto-systemic collateral vessels ${ }^{12}$. Tand, therefore, in such cases, neurological symptoms do not usually occur ${ }^{6}$.

Ultrasound parameters (periportal fibrosis grade, portal and splenic vein caliber and spleen longitudinal diameter) have been proposed to help define the clinical form of schistosomiasis and the presence of portal hypertension ${ }^{13}$. Furthermore, the use of portal Doppler ultrasound has been shown to detect flow changes even before the classic ultrasound findings ${ }^{14}$. Thus, the application of portal Doppler ultrasound in schistosomal myelitis (SM) may enhance the understanding of the splanchnic vascular scenario in this condition and throw some light on its possible influence in the migration of eggs and worms.

\section{METHOD}

The study protocol was approved by the institutional review board of the participating center (Hospital da Restauração) and patients gave written informed consent for data analysis.

The study consisted of an evaluation of portal flow conditions in patients with SM, and controls, who were carriers of intestinal or hepatointestinal forms of schistosomiasis, or were healthy individuals.

The target population (group I) were patients with $\mathrm{SM}$. For this diagnosis, the author used recommendations from the Centers for Disease Control (CDC) $)^{15}$. These included dysfunction of the thoracic or lumbosacral spinal cord; parasitological confirmation of the infection by Schistosoma mansoni and exclusion of other causes for transversal myelitis.

Group II were carriers of intestinal or hepatointestinal forms of schistosomiasis. This group was chosen based on the statements of Raso ${ }^{7}$ and Pitella ${ }^{12}$, who defined that SM was more common with these forms of systemic disease.

Group III were healthy control volunteers. With this group it was possible to define the normal values for the parameters in this study, and compare them with the statistical analyses.

The exclusion criteria, common for the three groups, were: (a) previous history of significant alcoholic intake; (b) presence of heart, lung or liver illness; (c) fever or other acute infections; (d) thrombosis of splenic or superior mesenteric vein; (e) regular use of adrenergic antagonist. The color Doppler ultrasound was obtained with a GE Logic $5{ }^{\circledR}$ machine, using a convex transducer with amplitude frequency between 2 and $5 \mathrm{MHz}$. For calculation of the portal transversal section area (TSA), the assumption of a cylinder vessel with a circular base was used ${ }^{16}$. The largest diameter (D) was defined in real time in B-mode, with a convex transducer of 2 to $5 \mathrm{MHz}$ in a longitudinal cut. The area was calculated by the formula, STA $=\pi$. $\mathrm{D}^{2} / 4$. The results were expressed in $\mathrm{cm}^{2}$. The portal venous velocity (PVV) was defined with a convex transducer of 2 to $5 \mathrm{MHz}$. The medium velocity was calculated in standard periods of time of four seconds, and the sample volume was 8 millimeters. The target was the center of the vessel, and an insonation angle of 60 degrees was used. The process was repeated three times for each patient. The results were expressed in $\mathrm{cm} / \mathrm{s}$. The portal venous flow (PVF) was defined as the product of TSA and PVV, thus PVF=TSA $\times$ PVV. The result was then multiplied by 60 , to obtain the value in $\mathrm{ml} /$ minute.

The congestion index $(\mathrm{CI})$ was calculated as the ratio between TSA and PVV (CI=TSA/PVV), and it was expressed in centimeters multiplied by seconds.

For comparative analyses of the quantitative variable in the three groups, the variance analyses test (ANOVA) was applied. To test contrasts, the Levene test was applied. For the analyses of qualitative variables, the chisquare or Fisher test was used. To measure associations, the prevalence ratio $(\mathrm{PR})$ was used. All conclusions were obtained within $5 \%$ of significance ${ }^{17,18}$. Excel 2000, SPSS 
Table 1. Distribution of the individuals in relation to gender.

\begin{tabular}{lccccc}
\hline & \multicolumn{4}{c}{ Gender } & \\
\cline { 2 - 5 } & \multicolumn{2}{c}{ Female } & \multicolumn{2}{c}{ Male } & p \\
\hline Groups & $\mathrm{n}$ & $\%$ & $\mathrm{n}$ & $\%$ & \\
Group I & 6 & 46.2 & 7 & 53.8 & \\
Group II & 7 & 70.0 & 3 & 30.0 & \\
Group III & 11 & 55.0 & 9 & 45.0 & 0.519 \\
\hline
\end{tabular}

8.0 and PRISM", version 3.02, 1999, GraphPad Software Incorporated were used.

\section{RESULTS}

A total group of 43 patients was evaluated by portal Doppler ultrasound, separated into three subgroups, as previously described. The groups were homogeneous according to gender ( $\mathrm{p}$-value $=0.519)$ (Table 1$)$. The mean age in group I was smaller than the others $(\mathrm{p}<0.05)$ (Table 2).

Abdominal ultrasound confirmed no liver abnormalities in groups I and III. In group II, there were three cases (30\%) of light periportal fibrosis, one of them in association with the enlargement of the left liver lobe.

Patients in group I showed, on average, a PVF much higher than that of patients in others groups $(p<0.001)$, which did not differ from each other (Fig 1). The same was found for PVV ( $\mathrm{p}<0.001$ ) (Fig 2). For the CI, no significant differences were seen among the groups $(\mathrm{p}=0.144)$ (Fig 3).

The normal values for PVF were obtained by analyzing group III. The calculation included the mean plus two standard deviations. It was defined that all results higher than $2019 \mathrm{ml} /$ minute represented overflow. As a measure of association between overflow and SM in patients with schistosomiasis (groups I and II), PR was used, giving a result of 3 (confidence interval of 1.47 to 6.14; $\mathrm{p}=0.0053$ ). This meant that SM was three times more prevalent among patients with schistosomiasis that developed overflow.

\section{DISCUSSION}

The comparative analyses of the three groups showed that they were homogeneous regarding gender, but not regarding age. This could suggest that there was selection bias.

The comparison of the results obtained in the portal Doppler ultrasound, showed a significant difference

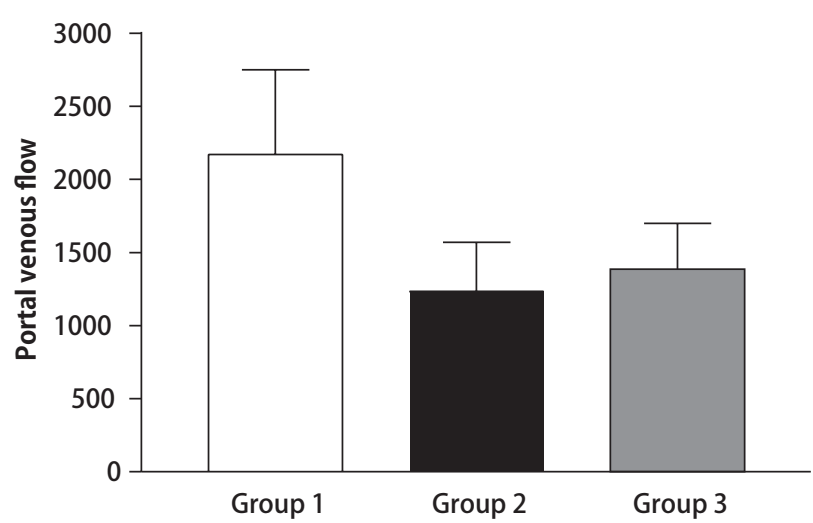

Fig 1. Graphic distribution of portal venous flow.

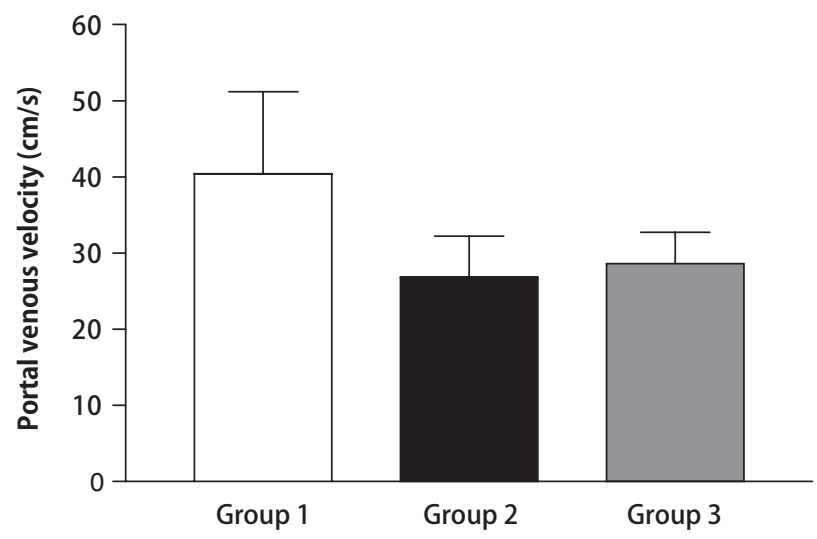

Fig 2. Graphic distribution of portal venous velocity.

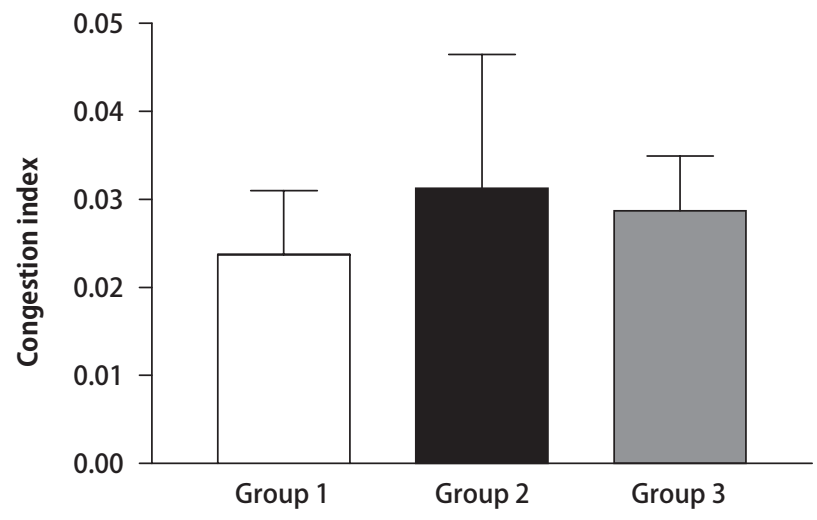

Fig 3. Graphic distribution of congestion index.

Table 2. Age distribution.

\begin{tabular}{lccccccc}
\hline & $\mathrm{n}^{*}$ & Min $^{* *}$ & Max $^{+}$ & Mean & St Dv $^{++}$ & $\mathrm{p}$ & Sig $^{\bullet}$ \\
\hline Group I & 13 & 15.0 & 47.0 & 27.3 & 9.8 & & \\
Group II & 10 & 22.0 & 49.0 & 39.0 & 10.0 & 0.013 & Group I $\times$ II \\
Group III & 20 & 21.0 & 65.0 & 39.5 & 13.1 & & Group I $\times$ III \\
\hline
\end{tabular}

${ }^{*}$ number; ${ }^{* *}$ minimum; ${ }^{+}$maximum; ${ }^{++}$standard deviation; ${ }^{\circ}$ significance. 
between group I and the others $(\mathrm{p}<0.001)$, in relation to the parameters that define the portal hemodynamic state (PVF and PVV). With these results, it can be assumed that in the patients of group I, hyperdynamic states of the portal circulation were more prevalent (overflow). To confirm this assumption, the PR demonstrated that SM was three times more prevalent among the patients with schistosomiasis that developed portal overflow (confidence interval of 1.47 to 6.14 ). The origin of this overflow condition could not be defined in this study. However, it probably differs from that of patients with hepatosplenic form of schistosomiasis, since they have a higher worm load, liver fibrosis and consequent portal hypertension syndrome ${ }^{19}$.

This cross-sectional study does not allow for causal inferences between the portal overflow state and the development of SM. Exposure to this variable may actually act as a causal factor, or it could merely be a consequence of the inflammatory response in the nervous system, determining the change in the splanchnic circulation.

The participation of humoral factors in the physiopathogenesis of the portal hypertension is well defined in the literature. A great emphasis has been given regarding its importance in the development and maintenance of this condition ${ }^{20-24}$. In the early stage of schistosomiasis, the sudden arrival of eggs in the liver unleash the formation of a large number of granulomas in a same evolution phase, and since then, there can be a release of some substances, like nitric oxide, that act by increasing the regional blood flow ${ }^{7,21,23,25}$.

The participation of eosinophilic cells in the immunological response to Schistosoma mansoni is intense, especially in acute forms of illness ${ }^{7}$, and these cells are, probably, responsible for the production of vasoactive intestinal peptide. This substance and the macrophages have fundamental importance in the regulatory formation of the granulomas ${ }^{7}$, and modification of regional conditions of blood flow. Therefore, it is pertinent to suppose that group I patients may develop an exacerbation of the immune allergic response to the eggs at the hepatic and intestinal level due to the humoral and inflammatory factors, leading to a hyperemic state of the splanchnic circulation.

The absence of porto-systemic shunts and the association of a portal hyperdynamic state can make this vascular bed more susceptible to flow reversions, when a sudden higher abdominal pressure occurs, like during some physical activities. Although a clear relation with previous physical effort was present in only $38.46 \%$ of the patients in this series, Peregrino et $\mathrm{al}^{2}$ reported this fact in $47.5 \%$ of their cases. On the other hand, this same author in 2002 wrote that $62.4 \%$ of the patients worked ion professions that led to constant abdominal effort ${ }^{26}$. Ferrari $^{27}$ defended the idea that increased abdominal pressure is a common event in daily activities like coughing, defecating etc., and it may not be present in anamnesis.

The CI evaluation did not demonstrate any significant differenced between the groups $(\mathrm{p}=0.144)$, although group II showed the highest mean, probably because of the light periportal fibrosis in $30 \%$ of cases. This index is appropriate for use in cirrhotic illness ${ }^{28}$, since it values the restrictive events of the flow. Therefore, in schistosomiasis, where there is a predominance of high dynamic conditions ${ }^{25}$, this may not be reliable.

The physiopathogenesis of portal hypertension may involve ${ }^{7}$ : (1) new periportal conjunctive formation; (2) vascular obstruction by granulomas or sometimes by worms; (3) destruction of the contractile portion and elasticity of the vascular wall by inflammation; (4) new periportal angiomatous formation. All these factors, essentially, are important for higher flow resistance. H however, their relevance is higher among the patients infrom group II, which can probably explains the higher CI values in this sample. The absence of statistic significance among the groups for the CI variant reinforces the notion that vasoactive substances are more important for the high dynamic state of circulation than for the restrictive events.

The diagnosis of neuroschistosomiasis is presumptive in most cases, with no specific examination to establish such a condition ${ }^{29}$. The high sensitivity of the Doppler ultrasound documented in this study suggests that it could be added to the diagnostic setting of patients with SM suspicion.

It needs to be asked why so few patients develop SM. The use of portal Doppler ultrasound and the verification of a high flow state may identify a population that is atunder risk of the developing myelitis, among those who suffer from the milder clinical forms of schistosomiasis.

The main contribution of this study derives from registering new hypotheses for the causal association. This study cannot answer the temporal dilemma of cause and effect. Moreover, the present sample was small and selected for conveniencet, and may not allow for extrapolations.

\section{REFERENCES}

1. Andrade AN. Neuroesquistossomose. Arq Neuropsiquiatr 1986;44:275-279.

2. Peregrino AJP, Oliveira SP, Porto CA, et al. Meningomielorradiculite por Shistosoma mansoni : Protocolo de investigação e registro de 21 casos. Arq Neuropsiquiatr 1988;46:49-60.

3. Santos EC, Campos GB, Diniz AC, Leal JC, Rocha MOC. Perfil clínico e critérios diagnósticos da mielorradiculopatia esquistossomótica. Arq Neuropsiquiatr 2001;59:772-777.

4. Spina-França A, Salum PNB, Limongi JCP, Berger A, Losso ER. Mielopatias: aspectos diagnósticos. Arq Neuropsiquiatr 1980;38:360-366.

5. Brito JCF, Nóbrega PV. Mielopatias: considerações clínicas e aspectos etiológicos. Arq Neuropsiquiatr 2003;61: 816-821.

6. Pitella JEH. The relation between involment of the central nervous system in schistosomiasis mansoni and forms of the parasitosis: a review. J Trop Med Hyg 1991;94:15-21.

7. Raso P. Esquistossomose mansônica. In: Filho GB (Ed). Bogliolo Patologia. Rio de Janeiro: Guanabara Kookan, 2000:1186-1207. 
8. Ferrari TCA, Moreira PRR, Cunha AS. Spinal-cord involvement in the hepato-splenic form of Schistosoma mansoni infection. Ann Trop Med Parasitol 2001;95:633-635

9. Batson OV. The function of the vertebral veins and their role in the spread of metastases. Ann Surg 1940;112:138-149.

10. Goss CM. As veias. In: Goss CM (Ed). Gray Anatomia. 29a Ed. Rio de Janeiro: Guanabara Koogan, 1988:552-597.

11. Ferrari TCA, Moreira PRR, Ferrari MLA, et al. Clinical and immunological study of schistomal myelorradiculopathy. Ann Trop Med Parasitol 1993;87:295-297.

12. Pitella JEH. Neuroschistosomiasis. Brain Pathol 1997;7:649-662.

13. Domingues ALC. Ultra-sonografia na esquistossomose mansônica hepatoesplênica: avaliação da intensidade da fibrose periportal e hipertensão portal. Tese de Doutorado, Universidade Federal de Pernambuco: Recife, 1998.

14. Sinha R. Grayscale and pulse Doppler characteristics of noncirrhotic portal fibrosis: a preliminary report. Clin Radiol 1999;54:154-159.

15. Centers for Disease Control and Prevention :Acute schistosomiasis with tranverse myelitis in American students returning from Kenia. Morb Mortal Wkly Rep 1984;33:446-447.

16. Lemos RS, Ferraz ÁB, Oliveira IRS, Ferraz EM. Dopplerfluxometria em portadores de esquistossomose hepatoesplênica: aspectos técnicos relacionados ao cálculo do fluxo sanguíneo portal e índice de congestão. Arq Bras Cir Dig 2003:16:134-138

17. Callegari-Jacques SM. Bioestatística: princípios e aplicações. Porto Alegre: Artmed, 2003.

18. Zar JH. Biostatistical analysis. $3^{\text {rd }}$ Ed. New Jersey: Prentice Hall, 1996.

19. Coutinho AD, Domingues ALC. Esquistossomose mansoni. In: Dani R, Castro LP (Eds). Gastroenterologia clínica. Rio de Janeiro: Guanabara Koogan, 1993:1697-1728.
20. Benoit JN, Barrowman JA, Harper SL, Kvietys PR, Granger DN. Role of humoral factors in the intestinal hyperemia associated with chronic portal hypertension. Am J Physiol 1984;247:486-493.

21. Li XN, Huang CT, Wang XH, et al. Changes of blood humoral substances in experimental cirrhosis and their effects on portal hemodynamics. Chin Med J (Engl) 1990;103:970-977.

22. Geraghty JG, Angerson WJ, Carter DC. Splanchnic haemodynamics and vasoactive agents in experimental cirrhosis. HPB Surg 1994;8:83-87.

23. Tsugawa K, Hashizume M, Migou S, et al. Role of nitric oxide and endothelin-1 in a portal hypertensive rat model. Scand J Gastroenterol 2000;35: 1097-1105.

24. Lopez-Talavera JC, Cadelina G, Olchowski J, Merrill W, Groszmann RJ. Thalidomide inhibits tumor necrosis factor alpha, decreases nitric oxide synthesis, and ameliorates the hyperdynamic circulatory syndrome in portal-hypertensive rats. Hepatology 1996;23:1616-1621.

25. Raia S, Mies Jr S. FA. Portal hypertension in mansonic schistosomiasis. World J Surg 1991;15:176-187.

26. Peregrino AJP, Puglia PMK, Nóbrega JPS, Livramento JA, Marques-Dias MJ, Scaff M. Esquistossomose medular: análise de 80 casos. Arq Neuropsiquiatr 2002;60:603-608.

27. Ferrari TCA. Spinal cord schistosomiasis : a report of 2 cases and review emphasizing clinical aspects. Medicine 1999;78:176-190.

28. Moriyasu F, Nishida O, Ban N, et al. "Congestion index" of portal vein. AJR 1985;146:735-739.

29. Santos EC. Perfil diagnóstico da mielorradiculopatia esquistossomótica em três hospitais de Belo Horizonte: estudo retrospectivo - 1972 a 1992. Dissertação Mestrado. Belo Horizonte: Faculdade de Medicina da UFMG, Belo Horizonte1994. 